\title{
Isotopic and lithologic variations of one precisely-dated stalagmite across the Medieval/LIA period from Heilong Cave, central China
}

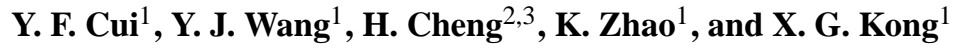 \\ ${ }^{1}$ College of Geography Science, Nanjing Normal University, Nanjing, 210097, China \\ ${ }^{2}$ Institute of Global Environment Change, Xi' an Jiaotong University, Xi' an, 710049, China \\ ${ }^{3}$ Department of Geology and Geophysics, University of Minnesota, Minneapolis, Minnesota, 55455, USA
}

Correspondence to: Y. J. Wang (yjwang@njnu.edu.cn)

Received: 28 March 2012 - Published in Clim. Past Discuss.: 17 April 2012

Revised: 26 August 2012 - Accepted: 13 September 2012 - Published: 11 October 2012

\begin{abstract}
Lithologic and isotopic changes of one stalagmite (224 mm in length) from Heilong Cave, Central China, are investigated here in order to explore multiple proxies of monsoon climate. High uranium concentrations (6-10 ppm) ensure Th-230 dates precisely and resultant chronology ranges from $\sim 790$ to $1780 \mathrm{AD}$ across the Medieval Warm Period (MWP) to Little Ice Age (LIA). Annually resolved oxygen and carbon isotopic data, gray level and elemental $\mathrm{Sr}$ are highly related to macroscopic lithologic changes. A lamination sequence is composed of alternations of white-porous and dark-compact calcite clearly discerned on the polished surface. The dark-compact laminae have low values of gray level, high $\mathrm{Sr}$ and $\delta^{13} \mathrm{C}$ values, indicating periods of low growth rate under dry climate conditions, and vice versa for the white-porous laminae. This suggests that changes in hydrology, matter input of drip water and crystallization process were controlled by cave environments and climates. The alternation of dry and wet periods with a significant periodicity of $\sim 90 \mathrm{yr}$, as indicated by spectral analyses of the multiple proxies, is further supported by a reconstructed precipitation index from historical documents and instrumental data extending back to $1470 \mathrm{AD}$. A strong coherence between monsoon proxy of calcite $\delta^{18} \mathrm{O}$ and the other proxies was observed during the LIA but not during the MWP. This is likely due to changes in atmospheric circulation pattern at the boundary of MWP/LIA. When the Intertropical Convergence Zone shifted southward during the LIA, summer monsoon precipitation at the cave site was probably dominated by the Mei-Yu, resulting in water vapor mainly originated from adjacent oceanic sources.
\end{abstract}

\section{Introduction}

The Medieval Warm Period (MWP) and Little Ice Age (LIA) are intensively studied climate episodes during the last two millennia (Bradley and Jones, 1992; Esper et al., 2002; Bradley et al., 2003). Numerous studies have investigated the spatial patterns and causal factors underlying them (Mann et al., 2009; Kaufman et al., 2009). The centennialscale oscillation involved a significant perturbation in tropical ocean temperatures as well as monsoon rainfall (Newton et al., 2006). The episodic and widespread Asian monsoon droughts during the LIA were thought to have played a major role in significantly changing regional society at that time (Cook et al., 2010; Buckley et al., 2010). However, it still remains unclear about the spatiotemporal pattern of the Asian monsoon rainfall and its forcing mechanism, partly due to inadequate high-resolution and long-term climate observations.

Considerable progresses in reconstructing Asian monsoon (AM) climate over the past millennia have been made using climate "proxy" data, such as ice cores (Thompson et al., 2000, Yang et al., 2007), tree rings (Cook et al., 2010; Buckley et al., 2010), lake sediments (Yancheva et al., 2007; Chu et al., 2009) and historical documents (Zheng et al., 2006; Tan et al., 2008). Speleothems are important terrestrial archives in recording AM climate for the past two millennia (Tan et al., 2003, 2006; Sinha et al., 2007, 2011; Zhang et al., 2008), as they have a great potential in well constrained dating, resolution and distribution (McDermott, 2004; Fairchild et al., 2006). The stalagmite $\delta^{18} \mathrm{O}$ signal has been extensively and successfully applied as a monsoon proxy, such as records 
from India and the Middle East (Sinha et al., 2011; Fleitmann et al., 2004, 2007) and data from China (Zhang et al., 2008; Wang et al., 2005; Hu et al., 2008). All of these $\delta^{18} \mathrm{O}$ records indicated a coherent monsoon pattern, with an increase in MWP and decrease in LIA. In East China, however, an integrated analysis of instrumental and historical records suggested a complex spatial rainfall pattern for the MWP and LIA, probably due to different responses of local rainfall to changes in regional monsoon intensity (Zhang et al., 2010). It is therefore necessary to utilize multiple proxies in stalagmite to investigate cave temperature, rainfall and vegetation response, in order to test the relationship between local climate changes and regional monsoon changes. Measurable parameters indicative of local environment changes include carbon isotope ratios, inter-annual thickness of growth laminae, trace element ratios, organic acid contents and the nature of trapped pollen grains (Fairchild et al., 2006).

Here, we explore multiple parameters from one stalagmite from Heilong Cave, Central China to investigate the climatic and environmental changes during the MWP and LIA. The trace-element and stable isotope variations have largely been accounted for progressive $\mathrm{CO}_{2}$ degassing and calcite precipitation from an initially saturated solution (Johnson et al., 2006), and may be related to seasonal rainfall changes. Additionally, the lithological changes, as alternations of annually deposited white-porous and dark-compact laminae, have been explained by the highly seasonal variations of the seepage water (Genty and Quinif, 1996). Two issues are of concern: (1) climatic relationship between macroscopic lithologic changes and multi-proxy sequences; and (2) shifts of monsoon circulation mode across the Medieval/LIA period, inferred from multiple parameters.

\section{Material and methods}

Heilong Cave $\left(31^{\circ} 40^{\prime} \mathrm{N}, 110^{\circ} 26^{\prime} \mathrm{E}\right.$, elevation $\left.1220 \mathrm{~m}\right)$ is located on the north slope of Mountain Shennongjia, over the middle reaches of Yangtze River Valley, Central China. Densely forested vegetation at the cave and surrounding area consists primarily of temperate deciduous broad-leaved plants. The cave was formed in Permian limestone, and is approximately $600 \mathrm{~m}$ in length with a narrow entrance. The relative humidity inside is close to $100 \%$. The highly seasonal climate in eastern China is dominated by the East Asian monsoon (EAM) (Fig. 1). The seasonality of present-day precipitation in eastern China varies from south to north (Wang and Lin, 2002). This south to north progression of high precipitation rates follows the path of the Mei-Yu front, a warm, humid, and convective subtropical frontal system that is related to the subtropical high pressure system over the western Pacific Ocean (Zhou et al., 2004 and references therein). Instrumental data of the past $30 \mathrm{yr}$ (1971-2000) in China display that Mei-Yu rainfalls (from 17 June to 8 July) are mainly distributed over the mid-low Yangtze River Valley,

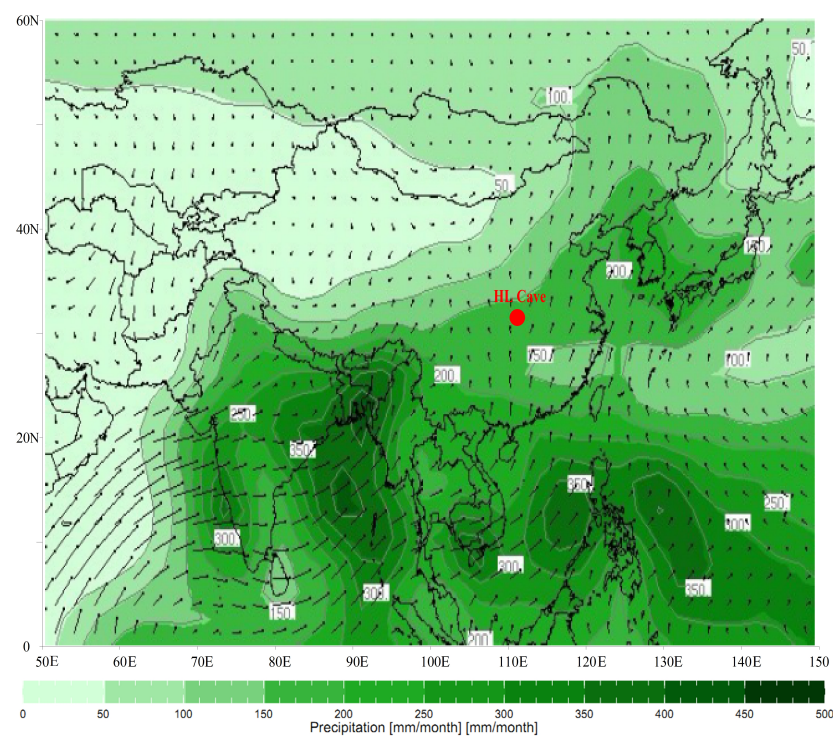

Fig. 1. Global mean July precipitation $\left(\mathrm{mm} \mathrm{month}^{-1}\right)$ within the longitudinal and latitudinal ranges of $50^{\circ} \mathrm{E}-150^{\circ} \mathrm{E}, 0^{\circ} \mathrm{N}-60^{\circ} \mathrm{N}$, including the site of Heilong Cave (HL, Central China, $31^{\circ} 40^{\prime} \mathrm{N}$, $110^{\circ} 26^{\prime} \mathrm{E}$, this study). Image from the Website: http://iridl.ldeo. columbia.edu/. The numbers in the figure show the monthly rainfall. Climatological wind vectors for the $925 \mathrm{hPa}$ pressure level indicate wind direction with speed proportional to the length of the vectors. The data source is NCEP, Climate Prediction Center USA.

with concentrated and intensive rainfall of $200-300 \mathrm{~mm}$, accounting for about $45 \%$ of total summer (June, July and August) rainfall amount (Ding and Chan, 2005; Ding et al., 2007). Heilong Cave, together with previously reported Sanbao (close to Heilong) (Wang et al., 2008) and Hulu Cave $(\sim 800 \mathrm{~km} \mathrm{E})$ (Wang et al., 2001$)$ are located within the Mei$\mathrm{Yu}$ frontal zone of the EAM system along which summer monsoon rains burst simultaneously in mid-June. The mean annual meteoric precipitation changes between $1000 \mathrm{~mm}$ and $1500 \mathrm{~mm}$. During boreal summer (June to August), the inflow of warm/humid air from equatorial Pacific penetrates into the Mt. Shennongjia, delivering more than $50 \%$ of total annual precipitation. Much less precipitation $(\sim 5 \%)$ occurs during the winter monsoon months (December to February). Mean annual surface temperature is about $8-13^{\circ} \mathrm{C}$, reaching a maximum in July (mean $\sim 22^{\circ} \mathrm{C}$ ) and a minimum in January $\left(\sim 1^{\circ} \mathrm{C}\right)$. Drip rate of seepage water inside the cave increases during the rainy seasons, and decreases dramatically during the dry seasons, following the seasonal cycle of local precipitation.

The columnar-shaped stalagmite BD is $224 \mathrm{~mm}$ in length, and its diameter ranges between 27 and $88 \mathrm{~mm}$. The sample was halved along the growth axis and polished, showing alternations of white-porous and dark-compact laminations (Fig. 2a). Fairly short sections present visible annual layers, identified with the naked eye (Fig. 2b, c), despite the fact that 


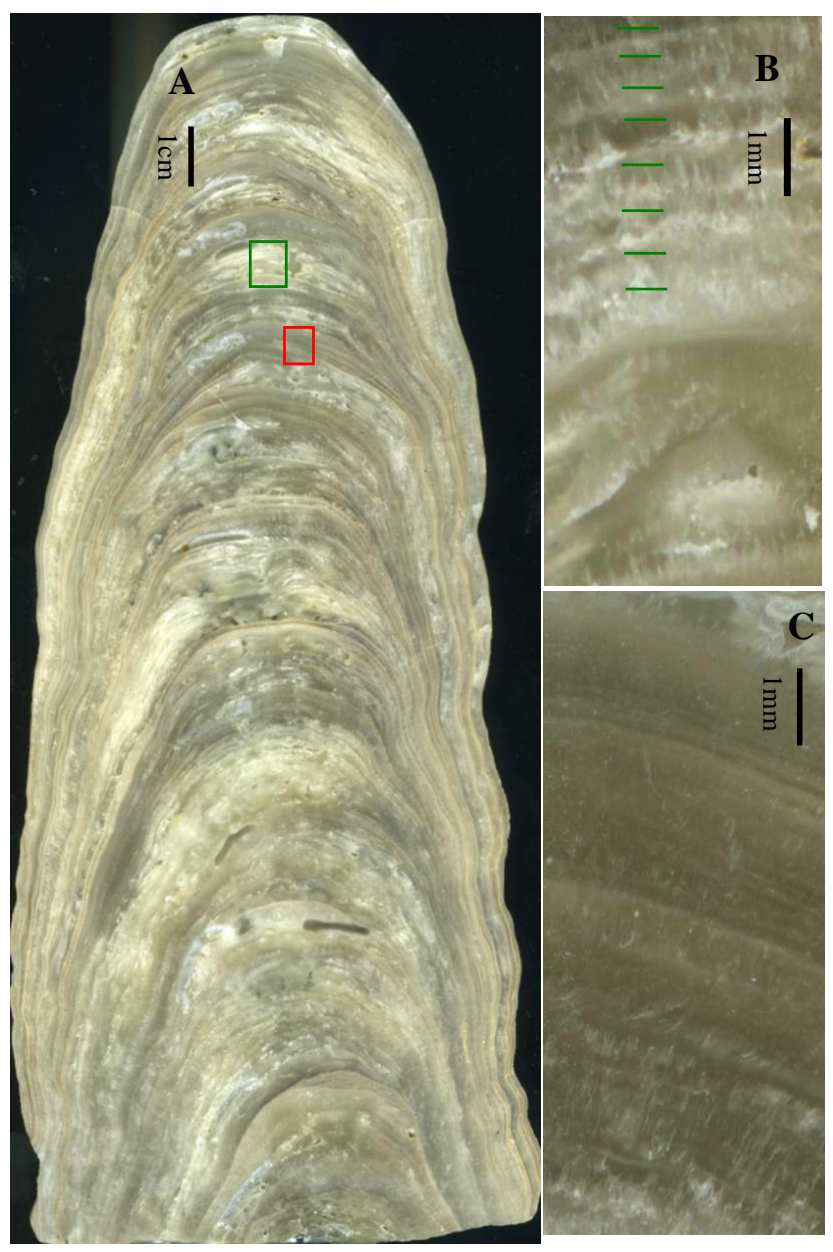

Fig. 2. (A) Polished surface of sample BD, showing lamination alternations of white-porous and dark-compact calcite. (B) A higher-magnification view of the area in the green rectangle in (A), displaying annual layers in white-porous calcite. (C) A higher-magnification view of the area in the red rectangle in (A), showing the examples of annual layers preserved in dark-compact lamination.

the annual laminations do not persist throughout the whole sequence.

Eleven sub-samples were collected for U-Th dating. Approximately $100 \mathrm{mg}$ samples of powder were extracted by milling along growth horizons with a hand-held carbide dental drill. Procedures for chemical separation and purification of uranium and thorium are similar to those described in Edwards et al. (1987) and Cheng et al. (2000). Measurements were performed on a Finnigan Element inductively coupled plasma mass spectrometer (ICP-MS), equipped with a double-focusing sector magnet and energy filter in reversed Nier-Johnson geometry and a MasCom multiplier, following procedures described in Shen et al. (2002). This work was performed at the Minnesota Isotope Laboratory, University of Minnesota.
A total of 1103 sub-samples were collected on average of every $0.2 \mathrm{~mm}$ along the central growth axis for isotopic analysis by knife shaving. The measurement was performed on a Finnigan-MAT 253 mass spectrometer fitted with a Kiel Carbonate Device at the College of Geography Science, Nanjing Normal University. Stable isotope measurements are similar to those described in Dykoski et al. (2005), with results that were reported relative to Vienna PeeDee Belemnite (VPDB) and with standardization determined relative to NBS19. Precision of $\delta^{18} \mathrm{O}$ values is $0.06 \%$, at the 1-sigma level.

A proxy of gray level was measured on a scanned picture of the polished surface taken with a high-resolution scanner. The data were obtained using ENVI software with a $4 \mathrm{~mm}$ wide traverse along the central growth axis. Gray levels vary between 20 and 250 with a mean of 99 . The trace element analyses were produced by the Avaatech XRF Core Scanner (X-ray fluorescence spectrometry), which is equipped with a variable optical system that enables any resolution between 10 and $0.1 \mathrm{~mm}$ (here $0.5 \mathrm{~mm}$ resolution). This work was performed at the Surficial Geochemical Laboratory, Nanjing University.

\section{Results}

\subsection{Chronology}

Eleven ${ }^{230} \mathrm{Th}$ dates are used to develop a chronology for the stalagmite BD (Fig. 3), with typical errors $(2 \sigma)$ of about $0.5 \%$ (Table 1). The resultant dates are in stratigraphic order and range from $860 \mathrm{AD}$ to $1780 \mathrm{AD}$, with most of the deposition across the MWP and LIA. Errors are small, from \pm 3 to $\pm 20 \mathrm{yr}$, due to high uranium concentrations (from 6 to $9.6 \mathrm{ppm}$ ). Over the dated interval, the average growth rate for the sample is $22.4 \mathrm{~mm} / 100 \mathrm{yr}$. An age model of the stalagmite is based on linear interpolation between ${ }^{230} \mathrm{Th}$ dates. Irrespective of the dating errors, the age uncertainties for this age model mainly come from the changing growth rate of whiteporous and dark-compact laminae. This age model probably enlarges the growth duration of the dark-compact laminae and reduces the duration of the white-porous laminae, but has little influence on periods of white-dark couplets. The average sampling interval for the stable isotope analyses is $\sim 1 \mathrm{yr}$.

\subsection{Proxy sequences}

Equilibrium calcite precipitation is important in order to interpret calcite $\delta^{18} \mathrm{O}$ in terms of climate. "Hendy Tests" (Hendy, 1971), performed on five individual growth laminae, show that $\delta^{18} \mathrm{O}$ variations along the same layer are less than $0.3 \%$ (Fig. 4a) and correlations between carbon and oxygen are statistically insignificant (Fig. 4b). These results indicate that the stalagmite calcite was deposited close to isotopic equilibrium and the $\delta^{18} \mathrm{O}$ signal is primarily of climatic origin. $\delta^{18} \mathrm{O}$ values range from $-9.2 \%$ to $-7.4 \%$, 
Table 1. Uranium and thorium isotopic compositions and ${ }^{230} \mathrm{Th}$ ages for sample BD by ICP-MS. The corrected ages are indicated in bold.

\begin{tabular}{|c|c|c|c|c|c|c|c|c|}
\hline sample & ${ }^{238} \mathrm{U}(\mathrm{ppb})$ & ${ }^{232} \mathrm{Th}(\mathrm{ppt})$ & $\begin{array}{r}{ }^{234} \mathrm{U} \\
\text { (measured) }\end{array}$ & $\begin{array}{r}{ }^{230} \mathrm{Th} /{ }^{238} \mathrm{U} \\
\text { (activity) }\end{array}$ & $\begin{array}{r}{ }^{230} \mathrm{Th} /{ }^{232} \mathrm{Th} \\
(\text { atomic } \times 10-6)\end{array}$ & $\begin{array}{r}\text { Age }(\mathrm{yr} \text { BP) } \\
\text { (uncorrected) }\end{array}$ & $\begin{array}{r}\operatorname{Age}(\mathrm{yr} \text { BP) } \\
\text { (corrected) }\end{array}$ & $\begin{array}{r}\text { Age }(\mathrm{yr} \text { AD) } \\
\text { (corrected) }\end{array}$ \\
\hline BD-1 mm & $9567 \pm 16$ & $1428 \pm 29$ & $49.5 \pm 2$ & 0.0022 & $246 \pm 5$ & $173 \pm 2$ & $169 \pm 3$ & $1781 \pm 3$ \\
\hline BD-16 mm & $7890 \pm 92$ & $2060 \pm 8$ & $48 \pm 7$ & 0.0028 & $176 \pm 3$ & $231 \pm 7$ & $224 \pm 8$ & $1726 \pm 8$ \\
\hline BD-29 mm & $6028 \pm 8$ & $3902 \pm 78$ & $51.9 \pm 2$ & 0.0035 & $90 \pm 2$ & $308 \pm 2$ & $290 \pm 13$ & $1660 \pm 13$ \\
\hline BD-58 mm & $7489 \pm 57$ & $2397 \pm 8$ & $42 \pm 5$ & 0.0061 & $313 \pm 3$ & $577 \pm 8$ & $569 \pm 9$ & $1381 \pm 9$ \\
\hline BD-75 mm & $8925 \pm 19$ & $2518 \pm 51$ & $46.1 \pm 2$ & 0.0068 & $396 \pm 8$ & $647 \pm 4$ & $639 \pm 7$ & $1311 \pm 7$ \\
\hline BD-95 mm & $7550 \pm 12$ & $1873 \pm 38$ & $49.8 \pm 2$ & 0.0073 & $488 \pm 10$ & $706 \pm 3$ & $699 \pm 6$ & $1251 \pm 6$ \\
\hline BD-106 mm & $8713 \pm 21$ & $4296 \pm 87$ & $43.8 \pm 2$ & 0.0079 & $263 \pm 5$ & $764 \pm 4$ & $750 \pm 11$ & $1200 \pm 11$ \\
\hline $\mathrm{BD}-126 \mathrm{~mm}$ & $7398 \pm 55$ & $2517 \pm 8$ & $41 \pm 5$ & 0.0093 & $450 \pm 3$ & $918 \pm 11$ & $909 \pm 12$ & $1041 \pm 12$ \\
\hline BD-148 mm & $8891 \pm 23$ & $4702 \pm 95$ & $42.1 \pm 2$ & 0.0098 & $307 \pm 6$ & $973 \pm 5$ & $958 \pm 12$ & $992 \pm 12$ \\
\hline BD-192 mm & $7943 \pm 12$ & $2260 \pm 45$ & $48.6 \pm 2$ & 0.0105 & $607 \pm 12$ & $1035 \pm 3$ & $1027 \pm 7$ & $923 \pm 7$ \\
\hline BD-207 mm & $7444 \pm 12$ & $7468 \pm 150$ & $49.9 \pm 2$ & 0.0113 & $185 \pm 4$ & $1118 \pm 20$ & $1090 \pm 20$ & $860 \pm 20$ \\
\hline
\end{tabular}

Errors are $2 \sigma$ analytical errors. Decay constant values are $\lambda_{230}=9.1577 \times 10^{-6} \mathrm{yr}^{-1}, \lambda_{234}=2.8263 \times 10^{-6} \mathrm{yr}^{-1}, \lambda_{238}=1.55125 \times 10^{-10} \mathrm{yr}^{-1}$. Corrected ${ }^{230} \mathrm{Th}$ ages assume an initial ${ }^{230} \mathrm{Th} /{ }^{232} \mathrm{Th}$ atomic ratio of $(4.4 \pm 2.2) \times 10^{-6}$. Year BP: year before present $(1950 \mathrm{AD})$.

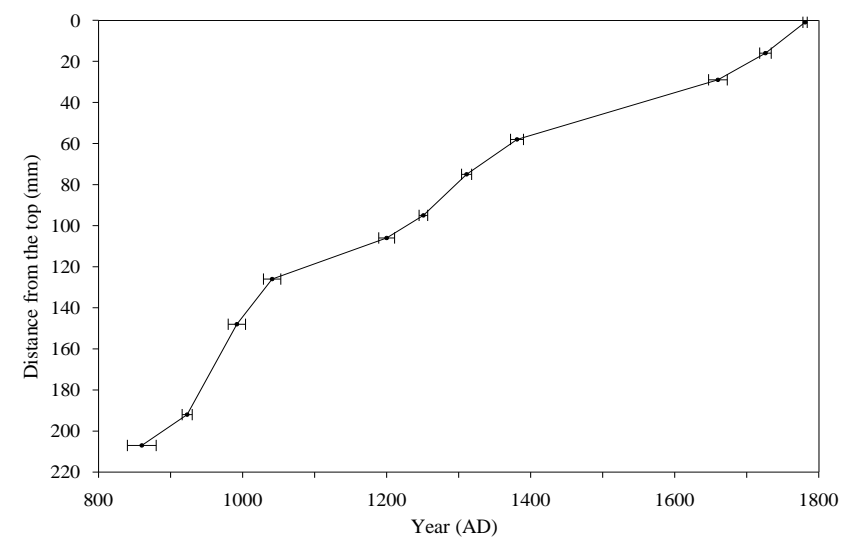

Fig. 3. $\mathrm{A}^{230}$ Th age model for the stalagmite BD. Black dots with error bars depict ${ }^{230} \mathrm{Th}$ dates with age errors less than $20 \mathrm{yr}$ (Table 1). The chronology was constructed by linear interpolation between ${ }^{230}$ Th dates.

with an overall mean of $-8.3 \%$ (Fig. 5). The $\delta^{18} \mathrm{O}$ profile exhibits significant fluctuations, and no long-term trend is observed throughout the whole profile. The amplitude seems larger during the interval of 0 and $73 \mathrm{~mm}$ (mainly covering the LIA) than the other part by approximately $0.13 \%$ o on average. Previous studies suggest that shifts in stalagmite $\delta^{18} \mathrm{O}$ largely reflect changes in $\delta^{18} \mathrm{O}$ values of meteoric precipitation (Cheng et al., 2006, 2009; Wang et al., 2001, 2008). Instrumental data from eastern China show that summer monsoon rainfall contributes significantly to the annual mean, with distinctly lower rainfall $\delta^{18} \mathrm{O}$ than during other seasons. The isotopic composition of modern precipitation from the nearest meteorological station of the study site (Wuhan, $30.62^{\circ} \mathrm{N}, 114.13^{\circ} \mathrm{E}$ ) exhibits a distinct seasonal signal (Araguás-Araguás et al., 1998). The weighted mean annual $\delta^{18} \mathrm{O}$ value for the period from 1988-1996 is $-7.0 \%$, with more negative values in summer months (average $-9.5 \%$, reported relative to Vienna Standard Mean Ocean Water (VSMOW)) and more positive $\delta^{18} \mathrm{O}$ in winter months (average $-4.5 \%$, VSMOW). Therefore, a changing ratio of low rainfall $\delta^{18} \mathrm{O}$ (transmitted by summer monsoon) was often invoked to explain the cave isotopic data (Wang et al., 2001), which is related to changes in the amount of summer monsoon precipitation or "summer monsoon intensity" (Cheng et al., 2006, 2009; Cai et al., 2010). However, instrumental data and simulation studies do not support the idea that variations in stalagmite $\delta^{18} \mathrm{O}$ values are caused by changes in precipitation amounts (Dayem et al., 2010; LeGrande and Schmidt, 2009). Dayem et al. (2010) suggested that the complex processes, i.e. different source regions of the precipitation, different pathways between the moisture sources and the cave sites, a different mix of processes involving condensation and evaporation within the atmosphere, or different types of precipitation should be taken into consideration. Recently, Pausata et al. (2011) proposed that Chinese stalagmite $\delta^{18} \mathrm{O}$ is controlled by changes in the Indian monsoon during a simulated Heinrich event, rather than by EAM. Cheng et al. (2012) reviewed speleothem records from both hemispheres and suggested that $\delta^{18} \mathrm{O}$ signal might record the Global Paleomonsoon characteristics that are analogous to a modern scenario. Therefore, the climatic interpretation of $\delta^{18} \mathrm{O}$ records remains a subject of considerable debate. In this study, we explore multiple parameters from one stalagmite in Heilong Cave to investigate the climatic information recorded in $\delta^{18} \mathrm{O}$ signal.

$\delta^{13} \mathrm{C}$ values range from $-14.9 \%$ o to $-10.5 \%$, with an average of $-12.4 \% \circ$ (Fig. 5). The $\delta^{13} \mathrm{C}$ curve shows a striking similarity to the $\delta^{18} \mathrm{O}$ during the interval of $0-73 \mathrm{~mm}$ (corresponding to the LIA) with five peaks and five troughs and notable differences in the remaining record (the MWP). The amplitude seems smaller during the LIA $(\sim 2.5 \%$ o $)$ in contrast to the MWP $\left(\sim 3.74 \%\right.$ ) (Fig. 6a). Variations of $\delta^{13} \mathrm{C}$ depend upon type of vegetation (C3 or $\mathrm{C} 4$ ), changes of $\mathrm{CO}_{2}$ 

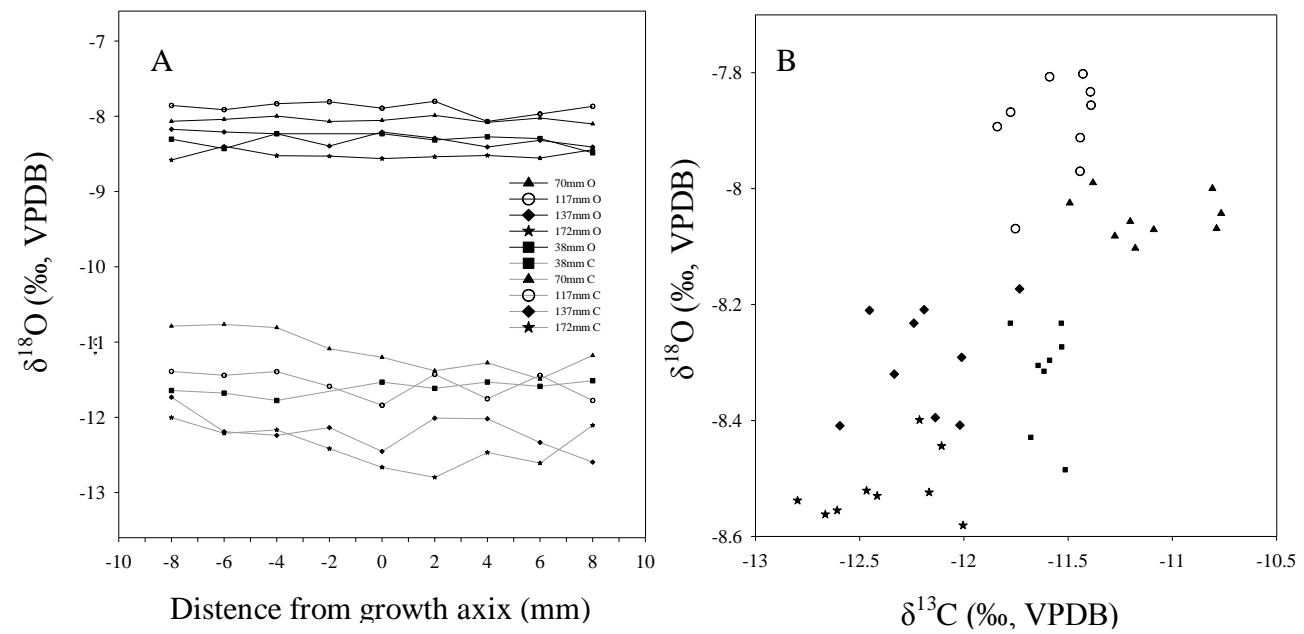

Fig. 4. The Hendy Tests for the stalagmite BD. (A) $\delta^{18} \mathrm{O}$ and $\delta^{13} \mathrm{C}$ profiles along five growth layers show no substantial isotopic fractionation. $\delta^{18} \mathrm{O}$ variations along the same layer are relative small $\left(<0.3 \%\right.$ o compared with the variations along the growth axis. (B) $\delta^{18} \mathrm{O}$ versus $\delta^{13} \mathrm{C}$ for growth layers. Correlations between $\delta^{18} \mathrm{O}$ and $\delta^{13} \mathrm{C}$ are statistically insignificant.

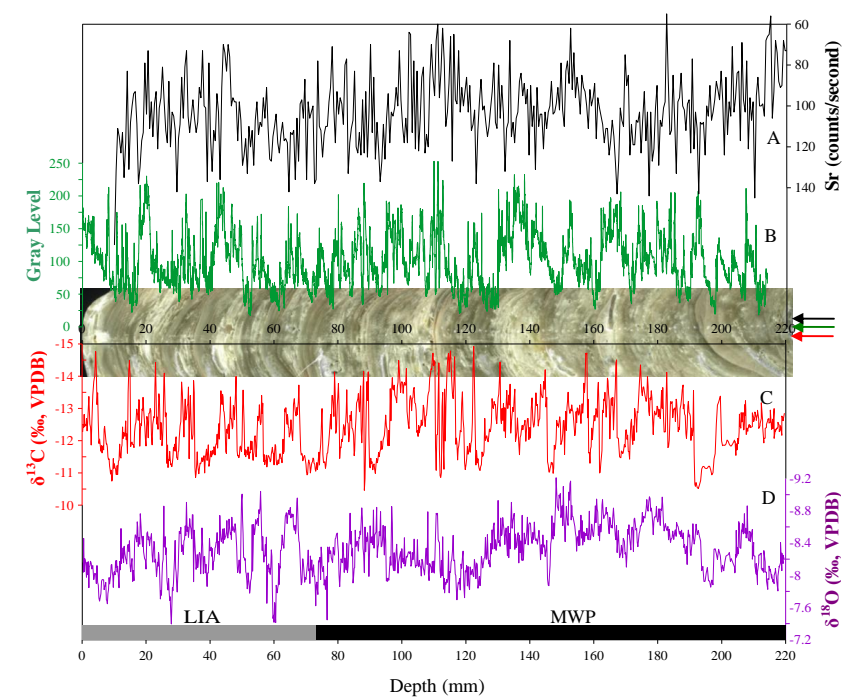

Fig. 5. Comparison between lithologic changes and multi-proxy records of stalagmite BD. (A) Sr record (Counts/Second, black curve); (B) Gray level record (green curve); (C) $\delta^{13} \mathrm{C}$ record (red curve); (D) $\delta^{18} \mathrm{O}$ record (purple curve). The sample photo is shown in the center for comparison. The black, green and red arrows indicate the analysis tracks of $\mathrm{Sr}$, gray level and stable isotope, respectively.

degassing, drip rate of water, bedrock dissolution rate and seasonal variations in soil $\mathrm{CO}_{2}$ in a complex fashion (Genty et al., 2001; McDermott et al., 2004; Fairchild et al., 2006). $\mathrm{CO}_{2}$ degassing is an important factor for the $\delta^{13} \mathrm{C}$ changes. Calcite deposition typically occurs by degassing of $\mathrm{CO}_{2}$ from carbonate-saturated drip-waters on entering the cave atmosphere (McDermott, 2004). Progressive $\mathrm{CO}_{2}$ degassing leads to increases in calcite $\delta^{13} \mathrm{C}$ due to the preferential loss of ${ }^{12} \mathrm{C}$ in degassed $\mathrm{CO}_{2}$. Studies in Heshang Cave (close to Heilong Cave) showed that a great fraction of $\mathrm{CO}_{2}$ degassing in dry periods resulted in high $\delta^{13} \mathrm{C}$ values, and vice versa (Johnson et al., 2006). Therefore, stalagmite $\delta^{13} \mathrm{C}$ records can be used as an indicator of local environmental changes.

Elemental $\mathrm{Sr}$ profile is illustrated in Fig. 5. Sr values generally range from 53 counts per second (cps) to $145 \mathrm{cps}$, with an average of $103 \mathrm{cps}$. Each measurement has a spatial resolution of $0.5 \mathrm{~mm}$ distance. The $\mathrm{Sr}$ profile exhibits significant fluctuations and no long-term trend is observed throughout the whole profile. Due to lack of cave monitoring, it is now difficult to assess the relative role of various influence factors on $\mathrm{Sr}$ variations. Here, we follow the traditional explanation of the Sr content. Since overlying limestone typically releases a significant amount of $\mathrm{Sr}$, transported downward by the seepage water, the $\mathrm{Sr}$ in speleothems is expected to derive mainly from the overlying limestone. Changes in the $\mathrm{Sr}$ content of a stalagmite can be controlled by dissolutionprecipitation processes in the unsaturated zone, due to differences in water residence time (Roberts et al., 1998; BarMatthews et al., 1999; Fairchild et al., 2000). Thus, Sr content in stalagmite can be used as an indicator of drip rate, and then likely reflects dry/wet conditions at the cave site.

\section{Discussions}

\subsection{Link between climatic and lithological changes}

As mentioned before, sample BD exhibits alternations of white-porous and dark-compact calcite. In Fig. 5, gray level directly reflects the macroscopic lithological changes, with high values corresponding to white-porous phases, whereas low values correspond to dark-compact phases. Comparison between $\delta^{13} \mathrm{C}$ and gray level shows a good relationship, 


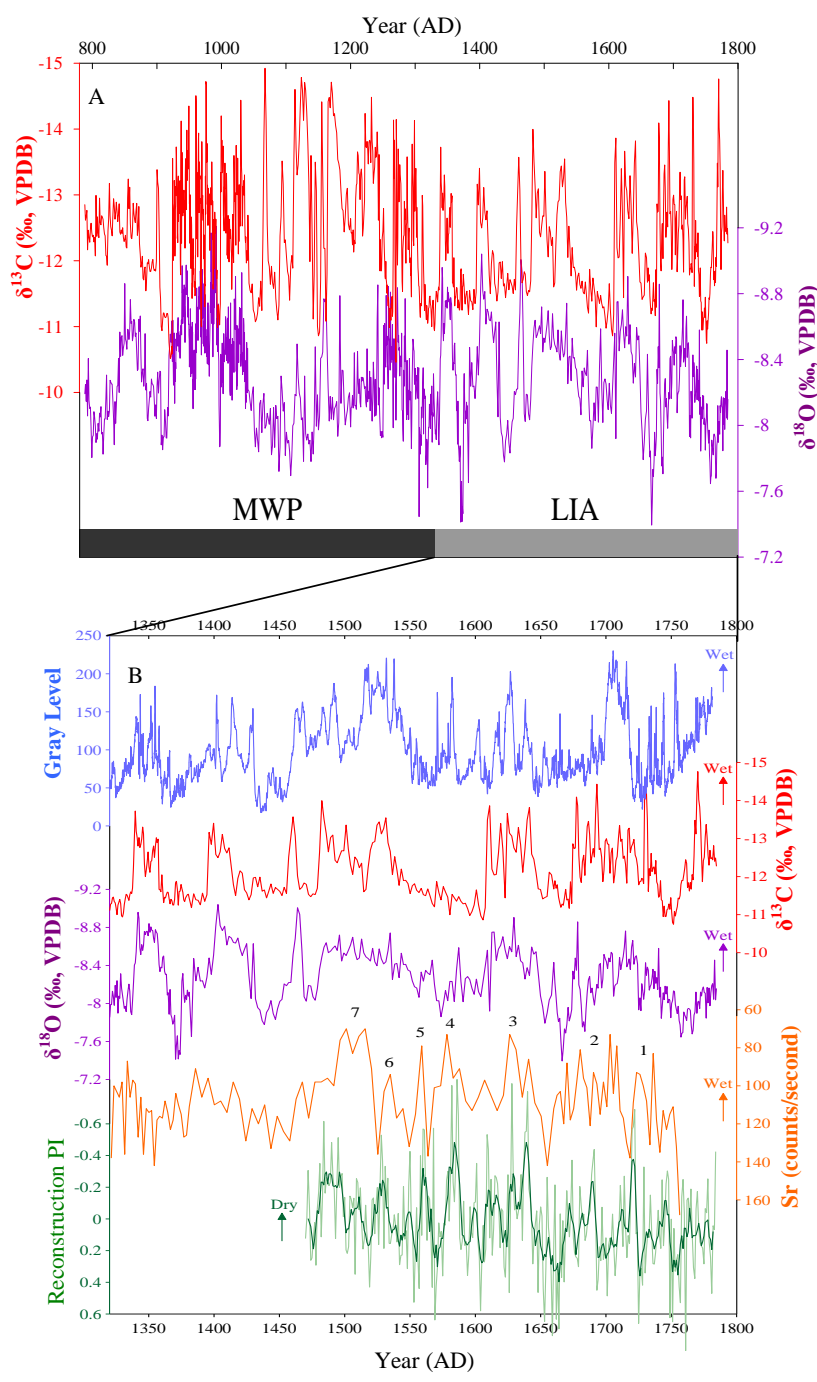

Fig. 6. (A) the $\delta^{18} \mathrm{O}$ (purple curve) and $\delta^{13} \mathrm{C}$ (red curve) time series. (B) detailed comparison of multi-proxy records from stalagmite BD and reconstruction precipitation index (PI) from Northern China (Yi et al., 2012), deep green line is 5-point running mean. The numbers indicate wet periods at the cave site over the mid-low Yangtze River Valley.

with negative excursions and positive excursions of $\delta^{13} \mathrm{C}$ values, corresponding to high (white-porous laminae) and low (dark-compact laminae) values with gray level (Fig. 5). The Sr profile shows a substantial similarity to gray level and $\delta^{13} \mathrm{C}$ curves. High $\mathrm{Sr}$ intensities are closely associated with the dark-compact laminae, while low to white-porous laminae (Fig. 5). However, there are some discrepancies between $\delta^{13} \mathrm{C}$, gray level and $\mathrm{Sr}$ curves, likely due to analysis errors from pore spaces on the polished surface (Fig. 2a) and different analysis tracks among them (Fig. 5).

As shown in Fig. 3, changes in growth rate can be divided into two distinct intervals. The first phase $(0-75 \mathrm{~mm}$ from the top, spanning the LIA), mostly composed of dark-compact laminae, has a growth rate of $\sim 15 \mathrm{~mm} / 100 \mathrm{yr}$. The second phase (75-220 mm, covering the MWP), with more whiteporous laminae, has a higher growth rate $(\sim 29 \mathrm{~mm} / 100 \mathrm{yr})$ (Fig. 5). The lowest growth rate $(\sim 10 \mathrm{~mm} / 100 \mathrm{yr})$ of the sample falls within the first part, from $29-58 \mathrm{~mm}$ depth, signaling the coldest period of LIA. The maximum growth rate interval ( $\sim 63 \mathrm{~mm} / 100 \mathrm{yr}$ ) between 148 to $192 \mathrm{~mm}$ depth was dated at the beginning of MWP. The changes in growth rate deduced from ${ }^{230} \mathrm{Th}$ dates can be further evaluated by the sparse and faint occurrence of annual-bands. In the whiteporous laminae, thickness of annual visible bands varies approximately from 300-900 $\mu \mathrm{m}$, averaging at $\sim 570 \mu \mathrm{m}$ (Fig. 2b). The white-dark paired laminae resemble the lightdark couplets described in a stalagmite from Heshang Cave (close to Heilong Cave, Johnson et al., 2006), probably due to a similar climate with a strong seasonality. In the darkcompact laminae, annual bands vary approximately from 45$120 \mu \mathrm{m}$, averaging at $\sim 85 \mu \mathrm{m}$ (Fig. 2c), close to those of annual microbanding in stalagmites from North China (Tan et al., 2006; Hou et al., 2002). These observations suggest that changes in growth rate are consistent with the macroscopic lithological changes, with high growth rate corresponding to white-porous laminae and low to dark-compact laminae.

Genty and Quinif (1996) proposed that annual variations of drip rate and super-saturation, due to seasonality in the seepage water, may produce some degree of crystalline coalescence, thus forming compact versus porous layers. In the same manner, the seasonal variation of compact versus porous layers could occur at a decadal-centennial timescale. In our study region where vegetation type is predominantly $\mathrm{C} 3$ forest, the influence of vegetation on stalagmite $\delta^{13} \mathrm{C}$ primarily reflects changes in the density of vegetative cover and biomass (Baldini et al., 2005). In dry years, limited vegetation growth and soil $\mathrm{CO}_{2}$ production could lead to a reduced biogenic $\mathrm{CO}_{2}$ and high speleothem $\delta^{13} \mathrm{C}$ values, and vice versa. Additionally, reduced/increased drip rates under dry/wet conditions could result in high/low speleothem $\delta^{13} \mathrm{C}$ values, owing to more/less time for $\mathrm{CO}_{2}$ degassing (BarMatthews et al., 1996; Mühlinghaus et al., 2007; Romanov et al., 2008). Therefore, a good relationship between $\delta^{13} \mathrm{C}$, $\mathrm{Sr}$ and visible lithological changes in sample BD suggests that dark-compact structures were formed under dry condition (low drip rate), and white-porous laminae were formed under wet condition (high drip rate).

\subsection{Monsoon changes across the MWP/LIA}

Intra-seasonal monsoon variability is dominated by "active" and "break" spells - two distinct oscillatory modes of monsoon that have radically different synoptic scale circulation and precipitation patterns (Annamalai and Slingo, 2001; Rajeevan et al., 2010). The seasonal cycle is a plausible analog for decadal-centennial scale strong/weak monsoon alternations. Lines of evidence suggest that stronger monsoon, related to northward shifts of the Intertropical Convergence 

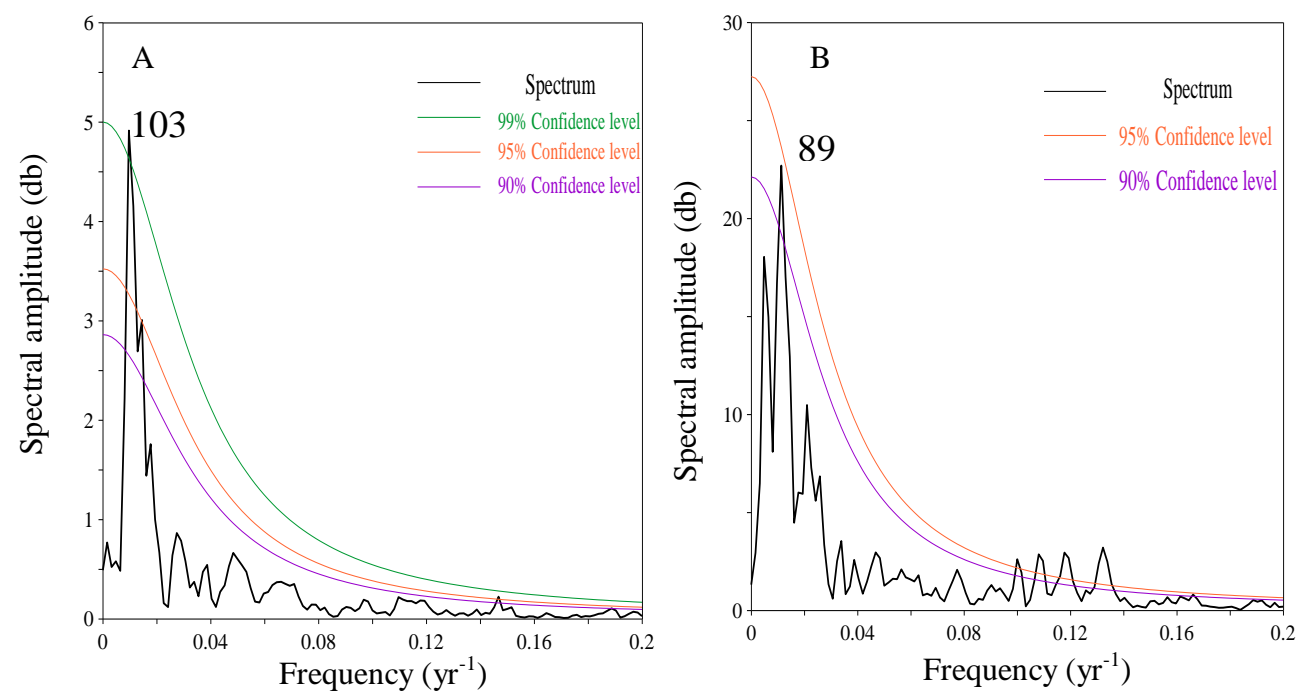

Fig. 7. Spectral analyses of the $\delta^{18} \mathrm{O}(\mathbf{A})$ and $\delta^{13} \mathrm{C}(\mathbf{B})$ records during LIA. Spectral peaks are labeled with their period (in yr). The spectra were calculated with software REDFIT (Schulz and Mudelsee, 2002).

Zone (ITCZ), may be associated with a protracted phase of the "active-dominated" mode during the MWP, and vice versa for the LIA (review in Sinha et al., 2011). As mentioned before, the relationship of the $\delta^{18} \mathrm{O}$ and $\delta^{13} \mathrm{C}$ series is strong during LIA, with a Pearson correlation coefficient of $0.46(n=407, p<0.001)$. The $\delta^{18} \mathrm{O}$ profile is also similar to gray level and $\mathrm{Sr}$ intensities during that period (Fig. 6b). In contrast, notable differences occur between the $\delta^{18} \mathrm{O}$ and the other proxies during MWP (790 to $1320 \mathrm{AD}$ ), with a low Pearson correlation coefficient of $\sim 0.18\left(\delta^{18} \mathrm{O}\right.$ vs. $\left.\delta^{13} \mathrm{C}\right)$ (Figs. 5 and 6a). This suggests that changes in large-scale monsoon circulation may be responsible for the coupling of the regional $\delta^{18} \mathrm{O}$ signal and the local environmental proxies since the beginning of LIA.

The Asian summer monsoon system consists mainly of the ITCZ (tropic monsoon trough) and the subtropical convergence zone (Mei-Yu front) (Tao and Chen, 1987). Meteorological studies have indicated an opposite relationship of intensities between ITCZ and Mei-Yu front (Zhang, 1998; Zhang and Tao, 1998; Zhang, 2001). Previous studies from Asia (Yancheva et al., 2007; Sinha et al., 2011), Africa (Verschuren et al., 2000; Brown and Johnson, 2005), South America (Reuter et al., 2009; Bird et al., 2011) and the Pacific Ocean (Oppo et al., 2009; Sachs et al., 2009) suggest that the ITCZ has shifted substantially to its southernmost position during the LIA. Under LIA colder climate conditions, the variability of the Mei-Yu front, associated with the shift of the western North Pacific subtropical high in its intensity and location, appears to have played a major role in transporting moisture to the cave site in the mid-low Yangtze River Valley. Therefore, the summer rainfall and its $\delta^{18} \mathrm{O}$ at the cave site were probably controlled by a single moisture source linked to Mei-Yu in LIA, which originates from adjacent oceanic sources, with strong Mei-Yu intensity related to heavy rainfall and negative $\delta^{18} \mathrm{O}$ values, and vice versa. Spectral analyses on the $\delta^{18} \mathrm{O}$ and $\delta^{13} \mathrm{C}$ records of stalagmite $\mathrm{BD}$ over the LIA show a significant peak at $\sim 100 \mathrm{yr}$ and $\sim 90 \mathrm{yr}$, respectively (Fig. 7). These quasi-periodicities are consistent with the centennial cycle for the length of Mei-Yu reconstructed by historical documents and instrumental data extending back to $1736 \mathrm{AD}$ (Ge et al., 2008) and the 90-yr oscillation exhibited in dry-wet indices of lower Yangtze River over the period 1470-1670 AD (Qian and Zhu, 2002). This suggests that the summer rainfall and its $\delta^{18} \mathrm{O}$ at the cave site probably reflected the Mei-Yu intensity during LIA.

The Mei-Yu control of the cave environment during the LIA is further supported by a comparison of a reconstructed summer (JJA) precipitation index by tree-ring and historical documents for North China (Yi et al., 2012) and our multiproxy profiles. As shown in Fig. 6b, within dating uncertainties, each of the seven wet intervals at the cave site has its corresponding dry episode over North China, supporting the hypothesis that changes in spatial rainfall pattern in China were controlled by the interaction between the tropical monsoon trough and the Mei-Yu front (Zhang and Tao, 1998; Ge et al., 2008), with weak (intense) tropical monsoon intensity corresponding to an intense (weak) Mei-Yu front, high (low) rainfall over the mid-low Yangtze River Valley, and low (high) precipitation over North China (Zhang, 2001; Qian et al., 2007). When the ITCZ shifted northward during the MWP (Sachs et al., 2009; Sinha et al., 2011), water vapor for the summer rainfall over the mid-low Yangtze River Valley may have been reached from a distant, tropical Indo-Pacific source and adjacent oceanic sources, leading to a complex relationship of rainfall $\delta^{18} \mathrm{O}$ and its amount. 


\section{Conclusions}

Based on 11 precise ${ }^{230} \mathrm{Th}$ dates and measurements of physical, elemental and isotopic proxies of one stalagmite from Heilong Cave, Central China, we reconstructed annuallyresolved monsoon climate changes from 790 to $1780 \mathrm{AD}$ covering the MWP and LIA. Three conclusions can be drawn from multi-proxy investigations as follows:

1. Macroscopic lithologic changes, with alternations of white-porous and dark-compact laminae, are highly related to variations of multi-proxy profiles, which were mainly controlled by changes of cave environments and climates on decadal-centennial time scales. In general, dark-compact laminae have low growth rate and gray level, high $\mathrm{Sr}$ intensities and $\delta^{13} \mathrm{C}$ values, indicating periods under dry conditions, and vice versa for whiteporous laminae. This suggests that macroscopic lithologic changes, analogous to seasonal fabric variations in annual laminae, can serve as an indicator of climatic or environmental changes.

2. High-resolution $\delta^{18} \mathrm{O}, \delta^{13} \mathrm{C}$, gray level and $\mathrm{Sr}$ profiles exhibit significant fluctuations without a long-term trend throughout the whole profiles. All records show low frequency oscillations in MWP and high frequency in LIA, with a significant periodicity of $\sim 90 \mathrm{yr}$ in LIA. The amplitude of $\delta^{13} \mathrm{C}$, gray level and $\mathrm{Sr}$ cycles is larger in MWP than that in LIA, but in an opposite sense to $\delta^{18} \mathrm{O}$. Contrasting with the MWP, $\delta^{18} \mathrm{O}$ and $\delta^{13} \mathrm{C}$ values are heavier and growth rate is lower during the LIA, indicating relatively drier conditions.

3. The relationship between the regional $\delta^{18} \mathrm{O}$ signal and the local environmental proxies $\left(\delta^{13} \mathrm{C}\right.$, gray level and Sr) switched to a coupled mode during the LIA, likely due to a shift in atmospheric circulation pattern across the MWP/LIA. When the ITCZ shifted southward during the LIA, water vapor and its $\delta^{18} \mathrm{O}$ at the cave site was probably dominated by a single moisture source linked to the Mei-Yu, resulting in a simple relationship between rainfall $\delta^{18} \mathrm{O}$ and its amount. Alternatively, when the ITCZ shifted northward during the MWP, water vapor may have reached from various moisture sources, leading to ambiguous relationship between rainfall $\delta^{18} \mathrm{O}$ and its amount.

Acknowledgements. This work was supported by the National Nature Science Foundation of China (grant No. 2007105GZ10033, 41202123), Basic Research Program of Jiangsu Province (grant No. BK2008025) and the CAS Strategic Priority Research Program (grant No. XDA05080503). We would also like to thank two anonymous reviewers for their comments.

Edited by: D. Fleitmann

\section{References}

Annamalai, H. and Slingo, J. M.: Active/break cycles: Diagnosis of the intraseasonal variability of the Asian summer monsoon, Clim. Dynam., 18, 85-102, 2001.

Araguás-Araguás, L., Froehlich, K., and Rozanski, K.: Stable isotope composition of precipitation over Southeast Asia, J. Geophys Res., 103, 28721-28742, 1998.

Baldini, J., McDermott, F., Baker, A., Baldini, L., Mattey, D., and Railsback, B.: Biomass effects on stalagmite growth and isotope ratios: a 20th century analogue from Wiltshire, England, Earth Planet. Sc. Lett., 240, 486-494, 2005.

Bar-Matthews, M., Ayalon, A., Matthews, A., Sass, E., and Halicz, L.: Carbon and oxygen isotope study of the active watercarbonate system in a karstic Mediterranean Cave: implication for palaeoclimate research in semiarid regions, Geochim. Cosmochim. Ac., 60, 337-347, 1996.

Bar-Matthews, M., Ayalon, A., Kaufman,A., and Wasserburg, G. J.: The Eastern Mediterranean paleoclimate as a reflection of regional events: Soreq Cave, Israel, Earth Planet. Sc. Lett., 166, 85-95, 1999.

Bird, B. W., Abbott, M. B., Vuille, M., Rodbell, D. T., Stansell, N. D., and Rosenmeier, M. F.: A 2,300-year-long annually resolved record of the South American summer monsoon from the Peruvian Andes, Proc. Natl. Acad. Sci. USA, 108, 8583-8588, 2011

Bradley, R. S. and Jones, P. D.: When was the "Little Ice Age"?, in: Proceedings of the International Symposium on the Little Ice Age climate, edited by: Mikami, T., Department of Geography, Tokyo Metropolitan University, 1-4, 1992.

Bradley, R. S., Hughes, M. K., and Diaz, H. F.: Climate in Medieval time, Science, 302, 404-405, 2003.

Brown, E. T. and Johnson, T. C.: Coherence between tropical East African and South American records of the Little Ice Age, Geochem. Geophy. Geosy., 6, Q12005, doi:10.1029/2005GC000959, 2005.

Buckley, B. M., Anchukaitis, K. J., Penny, D., Fletcher, R., Cook, E. R., Sano, M., Nam, L. C., Wichienkeeo, A., Minh, T. T., and Hong, T. M.: Climate as a contributing factor in the demise of Angkor, Cambodia, Proc. Natl. Acad. Sci. USA, 107, 67486752, 2010.

Cai, Y. J., Tan, L. C., Cheng, H., An, Z. S., Edwards, R. L., Kelly, M. J., Kong, X. G., and Wang, X. F.: The variation of summer monsoon precipitation in central China since the last deglaciation, Earth Planet. Sc. Lett., 291, 21-31, 2010.

Cheng, H., Edwards, R. L., Hoff, J., Gallup, C. D., Richards, D. A., and Asmerom, Y.: The half-lives of uranium-234 and thorium230, Chem. Geol., 169, 17-33, 2000.

Cheng, H., Edwards, R. L., Wang, Y. J., Kong, X. G., Ming, Y. F., Gallup, C. D., Kelly, M. J., Wang, X. F., and Liu, W. G.: A penultimate glacial monsoon record from Hulu Cave and two-phase glacial terminations, Geology, 34, 217-220, 2006.

Cheng, H., Edwards, R. L., Broecker, W. S., Denton, G. H., Kong, X. G., Wang, Y. J., Zhang, R., and Wang, X. F.: Ice age terminations, Science, 326, 248-251, 2009.

Cheng H., Sinha A., Wang X. F., Cruz F. W., and Edwards R. L.: The Global Paleomonsoon as seen through speleothem records from Asia and the Americas, Clim. Dynam., 39, 1045-1062, doi:10.1007/s00382-012-1363-7, 2012. 
Chu, G. Q., Sun, Q., Wang, X. H., Li, D., Rioual, P., Qiang, L., Han, J. T., and Liu, J. Q.: A 1600 year multi-proxy record of paleoclimatic change from varved sediments in Lake Xiaolongwan, northeastern China, J. Geophys Res., 114, D22108, doi:10.1029/2009JD012077, 2009.

Cook, E. R., Anchukaitis, K. J., Buckley, B. M., D’Arrigo, R. D., Jacoby, G. C., and Wright, W. E.: Asian Monsoon Failure and Megadrought During the Last Millennium, Science, 328, 486489, 2010

Dayem, K. E., Molnar, P., Battisti, D. S., and Roe, G. H.: Lessons learned from oxygen isotopes in modern precipitation applied to interpretation of speleothem records of paleoclimate from eastern Asia, Earth Planet. Sc. Lett., 295, 219-230, 2010.

Ding, Y. H. and Chan, J. C. L.: The East Asian summer monsoon: an overview, Meteorol. Atmos. Phys., 89, 117-142, 2005.

Ding, Y. H., Liu, J. J., Sun, Y., Liu, Y. J., He, J. H., and Song, Y. F.: A study of the synoptic-climatology of the Meiyu system in East Asia, Chinese Journal of Atmospheric Sciences, 31, 1082-1101, 2007.

Dykoski, C. A., Edwards, R. L., Cheng, H., Yuan, D. X., Cai, Y. J., Zhang, M. L., Lin, Y. S., Qing, J. M., An, Z. S., and Revenaugh, J.: A high-resolution, absolute-dated holocene and deglacial Asian monsoon record from Dongge Cave, China, Earth Planet. Sc. Lett., 233, 71-86, 2005.

Edwards, R. L., Cheng, J. H., and Wasserburg, G. J.: ${ }^{238}{ }^{2}-{ }^{234} \mathrm{U}-$ ${ }^{230} \mathrm{Th}-{ }^{232} \mathrm{Th}$ systematics and the precise measurement of time over the past 500,000 years, Earth Planet. Sc. Lett., 81, 175-192, 1986/1987.

Esper, J., Cook, E. R., and Schweingruber, F. H.: Low-frequency signals in long tree-ring chronologies for reconstructing past temperature variability, Science, 295, 2250-2253, 2002.

Fairchild, I. J., Borsato, A., Tooth, A. F., Frisia, S., Hawkesworth, C. J., Huang, Y., McDermott, F., and Spiro, B.: Controls on trace element (Sr-Mg) compositions of carbonate cave waters: implications for speleothem climatic records, Chem. Geol., 166, 255269, 2000

Fairchild, I. J., Smith, C. L., Baker, A., Fuller, L., Spötl, C., Mattey, D., McDermott, F., and Eimf.: Modification and preservation of environmental signals in speleothems, Earth-Sci. Rev., 75, 105153,2006

Fleitmann, D., Burns, S. J., Neff, U., Mudelsee, M., Mangini, A., and Matter, A.: Palaeoclimatic interpretation of highresolution oxygen isotope profiles derived from annually laminated speleothems from Southern Oman, Quaternary Sci. Rev., 23, 935-945, 2004.

Fleitmann, D., Burns, S. J., Mangini, A., Mudelsee, M., Kramers, J., Villa, I., Neff, U., Subbary, A.-A., Buettner, A., Hippler, D., and Matter, A.: Holocene ITCZ and Indian monsoon dynamics recorded in stalagmites from Oman and Yemen (Socotra), Quaternary Sci. Rev., 26, 170-188, 2007.

Ge, Q. S., Guo, X. F., Zheng, J. Y., and Hao, Z. X.: Meiyu in the middle and lower reaches of the Yangtze River since 1736, Chinese Sci. Bull., 53, 107-114, 2008.

Genty, D. and Quinif, Y.: Annually laminated sequences in the internal structure of some Belgian stalagmites-importance for paleoclimatology, J. Sediment. Res., 66, 275-288, 1996.
Genty, D., Baker, A., Massault, M., Procter, C., Gilmour, M., PonsBanchu, E., and Hamelin, B.: Dead carbon in stalagmites: carbonate bedrock paleodissolution vs. ageing of soil organic matter. Implications for ${ }^{13} \mathrm{C}$ variations in speleothems, Geochim. Cosmochim. Ac., 65, 3443-3457, 2001.

Hendy, C. H.: The isotopic geochemistry of speleothems-I. The calculation of the effects of different modes of formation on the isotopic composition of speleothems and their applicability as palaeoc limatic indicators, Geochim. Cosmochim. Ac., 35, 801824, 1971.

Hou, J. Z., Tan, M., and Liu D. S.: Counting chronology and climate records with about 1000 annual layers of a Holocene stalagmite from the Water Cave in Liaoning Province, China, Sci. China Ser. D, 54, 385-391, 2002.

Hu, C. Y., Henderson, G. M., Huang, J., Xie, S. C., Sun, Y., and Johnson, K. R.: Quantification of Holocene Asian monsoon rainfall from spatially separated cave records, Earth Planet. Sc. Lett., 266, 221-232, 2008.

Johnson, K. R., Hu, C. Y., Belshaw, N. S., and Henderson, G. M.: Seasonal trace-element and stable-isotope variations in a Chinese speleothem: The potential for high-resolution paleomonsoon reconstruction, Earth Planet. Sc. Lett., 244, 394-407, 2006.

Kaufman, D. S., Schneider, D. P., McKay, N. P., Ammann, C. M., Bradley, R. S., Briffa, K. R., Miller, G. H., Otto-Bliesner, B. L., Overpeck, J. T., Vinther, B. M., and Arctic Lakes 2k Project Members.: Recent Warming Reverses Long-Term Arctic Cooling, Science, 325, 1236-1239, 2009.

LeGrande, A. N. and Schmidt, G. A.: Sources of Holocene variability of oxygen isotopes in paleoclimate archives, Clim. Past, 5, 441-455, doi:10.5194/cp-5-441-2009, 2009.

Mann, M. E., Zhang, Z., Rutherford, S., Bradley, R. S., Hughes, M. K., Shindell, D., Ammann, C., Falugevi, G., and Ni, F.: Global Signatures and Dynamical Origins of the "Little Ice Age" and "Medieval Climate Anomaly", Science, 326, 1256-1260, 2009.

McDermott, F.: Paleo-climate reconstruction from stable isotope variations in spleothems: a review, Quaternary Sci. Rev., 23, 901-918, 2004.

Mühlinghaus, C., Scholz, D., and Mangini, A.: Modelling stalagmite growth and $\delta^{13} \mathrm{C}$ as a function of drip interval and temperature, Geochim. Cosmochim. Ac., 71, 2780-2790, 2007.

Newton, A., Thunell, R., and Stott, L. D.: Climate and hydrographic variability in the Indo-Pacific Warm Pool during the last millennium, Geophys. Res. Lett., 33, L19710, doi:10.1029/2006GL027234, 2006.

Oppo, D., Rosenthal, Y., and Linsley, B. K.: 2,000-year-long temperature and hydrology reconstructions from the Indo-Paci?c warm pool, Nature, 460, 1113-1116, 2009.

Pausata, F. S. R., Battisti, D. S., and Nisancioglu, K. H.: Chinese stalagmite $\delta^{18} \mathrm{O}$ controlled by changes in the Indian monsoon during a simulated Heinrich event, Nat. Geosci., 4, 474-480, 2011.

Qian, W. H. and Zhu, Y. F.: Little ice age climate near Beijing, China, inferred from historical and stalagmite records, Quaternary Res., 57, 109-119, 2002.

Qian, W. H., Lin, X., Zhu, Y. F., Xu, Y., and Fu, J. L.: Climatic regime shift and decadal anomalous events in China, Climatic Change, 84, 167-189, 2007.

Rajeevan, M., Gadgil, S., and Bhate, J.: Active and break spells of the Indian summer monsoon, J. Earth Syst. Sci., 119, 229-247, 2010 . 
Reuter, J., Stott, L., Khider, D., Sinha, A., Cheng, H., and Edwards, R. L.: A new perspective on the hydroclimate variability in northern South America during the Little Ice Age, Geophys. Res. Lett., 36, L21706, doi:10.1029/2009GL041051, 2009.

Roberts, M. S., Smart, P., and Baker, A.: Annual trace element variations in a Holocene speleothem, Earth Planet. Sc. Lett., 154, 237-246, 1998

Romanov, D., Kaufmann, G., and Dreybrodt, W.: $\delta^{13} \mathrm{C}$ pro?les along growth layers of stalagmites: comparing theoretical and experimental results, Geochim. Cosmochim. Ac., 72, 438-448, 2008.

Sachs, J. P., Sachse, D., Smittenberg, R. H., Zhang, Z. H., Battisti, D. S., and Golubic, S.: Southward movement of the Paci?c intertropical convergence zone AD 1400-1850, Nat. Geosci., 2, 519-525, 2009.

Schulz. M. and Mudelsee, M.: REDFIT: Estimating red-noise spectra directly from unevenly spaced paleoclimatic time series, Comput. Geosci., 28, 421-426, 2002.

Shen, C. C., Edwards, R. L., Cheng, H., Dorale, J. A., Thomas, R. B., Moran, S. B., Weinstein, S. E., and Edmonds, H. N.: Uranium and thorium isotopic concentration measurements by magnetic sector inductively coupled plasma mass spectrometry, Chem. Geol., 185, 165-178, 2002.

Sinha, A., Cannariato, K. G., Stott, L. D., Cheng, H., Edwards, R. L., Yadava, M. G., Ramesh, R., and Singh, I. B.: A 900 year $(600$ to 1500 A.D.) record of the Indian summer monsoon precipitation from the core monsoon zone of India, Geophys. Res. Lett., 34, L16707, doi:10.1029/2007GL030431, 2007.

Sinha, A., Stott, L., Berkelhammer, M., Cheng, H., Edwards, R. L., Buckley, B., Aldenderfer, M., and Mudelsee, M.: A global context for megadroughts in monsoon Asia during the past millennium, Quaternary Sci. Rev., 30, 47-62, 2011.

Tan, M., Liu, T. S., Hou, J. Z., Qin, X. G., Zhang, H. C., and Li, T. Y.: Cyclic rapid warming on centennial-scale revealed by a 2650 year stalagmite record of warm season temperature, Geophys. Res. Lett., 30, 191-194, 2003.

Tan, M., Baker, A., Genty, D., Smith, C., Esper, J., and Cai, B. G.: Applications of stalagmite laminae to paleoclimate reconstructions: Comparison with dendrochronology/climatology, Quaternary Sci. Rev., 25, 2103-2117, 2006.

Tan, L. C., Cai, Y. J., Yi, L., An Z. S., and Ai, L.: Precipitation variations of Longxi, northeast margin of Tibetan Plateau since AD 960 and their relationship with solar activity, Clim. Past, 4, 19-28, doi:10.5194/cp-4-19-2008, 2008.

Tao, S. Y. and Chen, L. X.: A review of recent research on the East Asina summer monsoon in China, in: Monsoon Meteorology, edited by: Chang, C. P. and Krishnamurti, T. N., UK, Oxford University Press, 60-92, 1987.

Thompson, L. G., Yao, T., Mosley-Thompson, E., Davis, M. E., Henderson, K. A., and Lin, P. N.: A high-resolution millennial record of the South Asian monsoon from Himalayan ice cores, Science, 289, 1916-1919, 2000.

Verschuren, D., Laird, K. R., and Cumming, B. F.: Rainfall and drought in equatorial east Africa during the past 1100 years, Nature, 403, 410-414, 2000.
Wang, B. and Lin, H.: Rainy season of the Asian-Pacific summer monsoon, J. Climate, 15, 386-396 2002.

Wang, Y. J., Cheng, H., Edwards, R. L., An, Z. S., Wu, J. Y., Shen, C. C., and Dorale, J. A.: A high-resolution absolute-dated late Pleistocene monsoon record from Hulu Cave, China, Science, 294, 2345-2348, 2001.

Wang, Y. J., Cheng, H., Edwards, R. L., He, Y. Q., Kong, X. G., An, Z. S., Wu, J. Y., Kelly, M. J., Dykoski, C. A., and Li, X. D.: The Holocene Asian monsoon: links to solar changes and North Atlantic climate, Science, 308, 854-857, 2005.

Wang, Y. J., Cheng, H., Edwards, R. L., Kong, X. G., Shao, X. H., Chen, S. T., Wu, J. Y., Jiang, X. Y., Wang, X. F., and An, Z. S.: Millennial- and orbital-scale changes in the East Asian monsoon over the past 224,000 years, Nature, 451, 1090-1093, 2008.

Yancheva, G., Nowaczyk, N. R., Mingram, J., Dulski, P., Schettler, G., Negendank, J. W., Liu, J. Q., Sigman, D. M., Peterson, L. C., and Haug, G. H.: Influence of the intertropical convergence zone on the East-Asian monsoon, Nature, 445, 74-77, 2007.

Yang, B., Braeuning, A., Yao, T. D., and Davis, M. E.: Correlation between the oxygen isotope record from Dasuopu ice core and the Asian Southwest Monsoon during the last millennium, Quaternary Sci. Rev., 26, 1810-1817, 2007.

Yi, L., Yu, H. J., Ge, J. Y., Lai, Z. P., Xu, X. Y., Qin, L., and Peng, S. Z.: Reconstruction of annual summer precipitation and temperature in north-central China since $1470 \mathrm{AD}$ based on drought/flood index and tree-ring records, Climatic Change, 110, 469-498, doi:10.1007/s10584-011-0052-6, 2012.

Zhang, D. E., Li, H. C., Ku, T. L., and Lu, L. H.: On linking climate to Chinese dynastic change: Spatial and temporal variations of monsoonal rain, Chinese Sci. Bull., 55, 77-83, 2010.

Zhang, P. Z., Cheng, H., Edwards, R. L., Chen, F. H., Wang, Y. J., Yang, X. L., Liu, J., Tan, M., Wang, X. F., Liu, J. H., An, C. L., Dai, Z. B., Zhou, J., Zhang, D. Z., Jia, J. H., Jin, L. Y., and Johnson, K. R.: A Test of Climate, Sun, and Culture Relationships from an 1810-Year Chinese Cave Record, Science, 322, 940-942, 2008.

Zhang, Q. Y.: The relationship between the east summer Asia monsoou and the india monsoon, in: East Asia Monsoon and Storm in China, edited by: Institute of Atmospheric Physics, Chinese Academy of Sciences, Beijing, Meteorological Press, 266-273, 1998.

Zhang, Q. Y. and Tao, S. Y.: East Asia tropical and subtropical monsoons in the summer and precipitation in Eastern China in wet season, J. Appl. Meteorol. Sci., 9(Suppl.), 16-23, 1998.

Zhang, R. H.: Relations of water vapor transport from Indian monsoon with that over East Asia and the summer rainfall in China, Adv. Atmos. Sci., 18, 1005-1017, 2001.

Zheng, J. Y., Wang, W. C., Ge, Q. S., Man, Z. M., and Zhang, P. Y.: Precipitation variability and extreme events in eastern China during the past 1500 years, Terr. Atmos. Ocean. Sci., 17, 579592, 2006.

Zhou, Y. S., Gao, S. T., and Shen, S. S. P.: A diagnostic study of formation and structures of the Meiyu Front System over East Asia, J. Meteorol. Soc. Japan, 82, 1565-1576, 2004. 